\title{
Spontaneous and mutagen induced sister chromatid exchange in multiple sclerosis
}

\author{
VIJAYALAXMI*, M S NEWTON*, C M STEEL*, H J EVANS*, \\ AND B PENTLAND†
}

From*the MRC Clinical and Population Cytogenetics Unit, Western General Hospital, Edinburgh, and $\dagger$ the Rehabilitation Medicine Unit, University of Edinburgh, Astley Ainslie Hospital, Edinburgh.

SUMMARY Spontaneous and mutagen induced sister chromatid exchange (SCE) frequencies have been studied in nine patients with multiple sclerosis and in nine age and sex matched healthy controls. The incidence of spontaneous SCE in lymphocytes of the MS patients was significantly greater, by about $50 \%$, than in those of the control subjects. When exposed to mitomycin C (MMC) or ethyl methane sulfonate (EMS) in vitro, cells from both groups showed typical dose dependent increases in SCE frequency, with yields from MS patients slightly higher than from controls. The higher SCE yields in mutagen treated MS cells relative to controls is considered to reflect initial basal differences between the cell types, so that MS cells are not intrinsically hypersensitive to mutagen treatment.

Multiple sclerosis (MS) is a common disease of the nervous system affecting about 50000 people in the United Kingdom. The highest prevalance of MS in the world is in the Orkney and Shetland Isles. ${ }^{1}$ The onset of the disease is usually between 15 and 50 years of age and the incidence in females outnumbers that in males by $1 \cdot 4: 1$. The disease has been recognised for the past century but the exact cause is still unknown. Investigations on histocompatibility antigens $\mathrm{s}^{2-4}$ and family studies showing that about $10 \%$ of patients with MS have an affecied relative ${ }^{5}$ reveal an influence of genetic factors associated with the susceptibility to the disease, and epidemiological studies point to the possible role of viral infection. ${ }^{6}$ Many other correlations implicating $\operatorname{diet}^{7}$ and geoclimatic and socioeconomic variables ${ }^{5} 8$ have also been reported. Recent studies indicate abnormalities in circulating immunoregulatory cells correlating very well with disease activity, ${ }^{9}$ and Waksman ${ }^{10}$ has postulated that MS occurs in genetically predisposed persons manifesting defects in immune regulation, triggered by viral infection or autoimmune in nature.

Early neuronal degeneration associated with impaired immune response is characteristic of a number of inherited diseases in man including ataxia telangiectasia (AT). AT cells also show enhanced response to cell killing and production of chromosomal aberrations following exposure to a variety of mutagens, suggesting a defect in the repair of

Received for publication 30 March 1983

Accepted for publication 5 April 1983. damaged DNA. ${ }^{11-13}$ A similar mutagen hypersensitivity has been well established in xeroderma pigmentosum (XP), another autosomal recessive disease associated with neurological abnormalities and defects in DNA repair. ${ }^{14}$ These observations have led to the proposition that DNA repair is required for the functional integrity of the nervous system and the premature death of neurones damaged in vivo by endogenous chemicals might be the consequence of inefficient DNA repair. Such a sequence of events has been postulated in other degenerative diseases of the nervous system, in addition to AT and XP. ${ }^{15}{ }^{16}$ Two recent reports have indicated a raised incidence of spontaneous sister chromatid exchange (SCE) and of $x$-ray induced chromosomal aberrations in the lymphocytes of MS patients, pointing to the possibility of an inherited abnormality in DNA repair in this condition. ${ }^{17} 18$ We have examined this possibility and in the present paper report on the incidence of spontaneous and mutagen induced SCE in the lymphocytes of nine MS patients and matched controls and conclude that MS is not associated with mutagen hypersensitivity.

\section{Materials and methods}

The nine patients studied, four males and five females, were unrelated and their ages ranged from 25 to 56 years (mean 41 years). All of the patients satisfied the criteria described by McDonald and 
Halliday ${ }^{19}$ of clinically definite multiple sclerosis. Symptoms had been present for from 3 to 27 years (mean 10 years) at the time of blood sampling, two of the patients had been treated with antibiotics and analgesics not known to cause chromosome damage, and one had completed a three day course on dexamethasone just before study. Heparinised whole blood was collected from the nine patients and from an equal number of age and sex matched healthy controls. From each subject, separate cultures were set up each using $0.8 \mathrm{ml}$ blood in $10 \mathrm{ml}$ RPMI 1640 medium containing $20 \%$ fetal calf serum, $1 \%$ PHA (Wellcome), $1 \%$ glutamine, $100 \mathrm{U}$ penicillin, $100 \mu \mathrm{g}$ streptomycin, and $25 \mu \mathrm{mol} / \mathrm{l} \mathrm{BrdU}$. Mitomycin C (MMC, Kyowa, Japan) dissolved in distilled water was immediately added to one set of cultures to give final concentrations of $10^{-8}, 3 \times 10^{-8}$, and $10^{-7}$ $\mathrm{mol} / 1$. Ethylmethanesulfonate (EMS, Koch-Light Laboratories) dissolved in distilled water was added to a second set of cultures to give final concentrations of $10^{-4}, 3 \times 10^{-4}$, and $10^{-3} \mathrm{~mol} / 1$. All cultures were kept in the dark at $37^{\circ} \mathrm{C}$ for 72 hours and were treated with $5 \times 10^{-7} \mathrm{~mol} / \mathrm{l}$ colchicine for the last 2 hours. The cells were then collected, treated with $75 \mathrm{mmol} / \mathrm{l}$ potassium chloride for 8 minutes, fixed in 3:1 methanol acetic acid mixture, and dropped onto slides which were air dried. The fluorescence plus Giemsa technique ${ }^{20}$ was used for differential chromatid staining and all slides were randomised, coded, and scored blind. From each culture, 20 metaphases showing typical harlequin staining were examined to record the frequency of SCE.

\section{Results and discussion}

The spontaneous incidence of SCE in the cells from nine MS patients $(11 \cdot 8 \pm 0 \cdot 43)$ is significantly higher $(\mathrm{p}<0.001)$ than in those of the nine healthy controls $(7 \cdot 2 \pm 0 \cdot 34$, fig 1$)$, a result which confirms and extends the initial findings of Sutherland et al. ${ }^{17}$ The proportions of cells showing different numbers of SCE are shown in fig 2 which again demonstrates a clear difference in the distributions between the groups.

There is disagreement on the question of whether PHA responsiveness is depressed in blood lymphocytes from MS patients, particularly during the active phase of the disease, ${ }^{21-25}$ and there is evidence that the rate of cell proliferation has an effect on both spontaneous and mutagen induced SCE frequencies. ${ }^{26} 27$ In our studies we found no evidence for an abnormal response of MS lymphocytes to PHA stimulation. The use of BrdU and FPG staining provides an unambiguous identification of cells in their first, second, and third or later division in 72 hour culture, and the proportions of dividing cells at these divisions provides a measure of

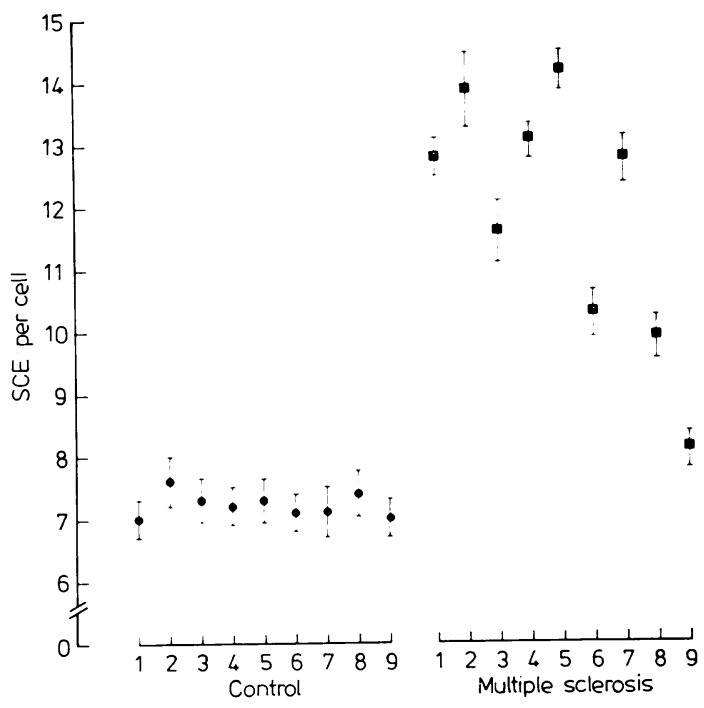

FIG 1 Individual mean SCE frequency ( $\pm S E$ scored from 20 second division metaphases) in nine controls (O) and nine MS patients (Q).

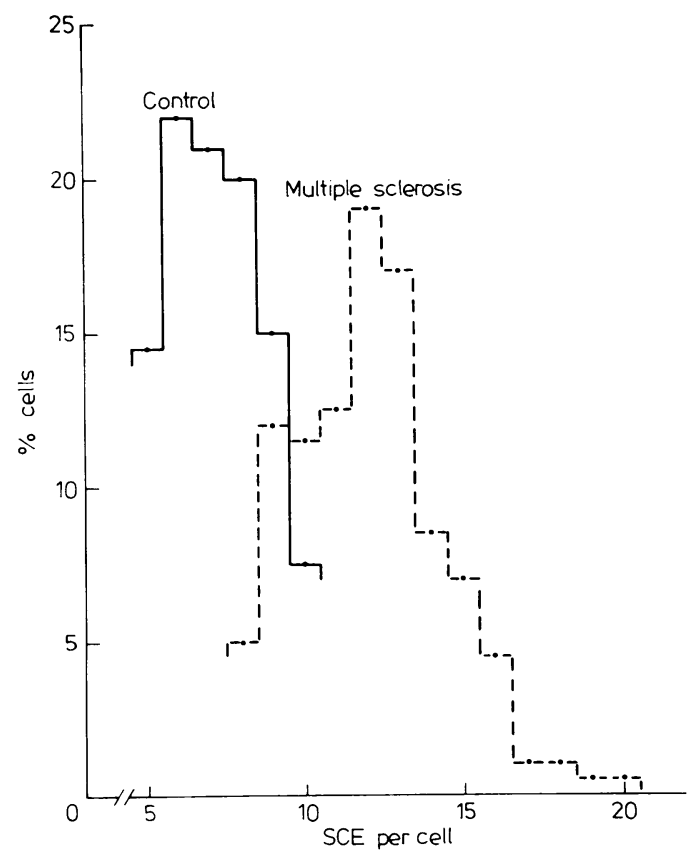

FIG 2 Percentage of cells showing different number of $S C E$ from nine controls and nine MS patients. A total of 180 cells was examined in each group. 
proliferation rate. In 200 mitoses counted from each subject, the respective mean indices found were $22 \%$, $42 \%$, and $36 \%$ in controls and $18 \%, 48 \%$, and $34 \%$ in MS patients. These results thus suggest that, relative to controls, neither the response to PHA nor the rate of cell proliferation is altered in MS patients and the observed difference in their spontaneous SCE frequency is not the result of either of these parameters. The possibility that the drugs taken by the patients could be responsible for increasing the SCE must be considered, but so far none of these drugs has been shown to have adverse cytogenetic effects.

Whether the increase in SCE frequency in MS patients might be the result of the other factors associated with the disease is worth consideration. Epidemiological studies provide strong support for the hypothesis that MS is initiated by virus infection and evidence has been advanced to incriminate various types of virus infection as causal factors in MS. ${ }^{28-33}$ Viral infection, both in vivo and in vitro, is well known to be associated with the induction of chromosomal aberrations, ${ }^{\mathbf{3 4 - 3 6}}$ but there is no indication of an increased chromosomal aberration frequency in blood lymphocytes of MS patients. Our own unpublished results on the lymphocytes from 50 subjects immunised with attenuated influenza and poliomyelitis virus have also revealed small, but significant, increases in SCE as compared to controls. The mechanisms resulting in increased SCE in immunised subjects is unknown, but changes in SCE incidence could reflect changes in the efficiency with which cells take up BrdU or subtle alterations in the proportion of circulating lymphocyte subsets.
Abnormalities in circulating immunoregulatory $\stackrel{\overparen{\Phi}}{\stackrel{\oplus}{*}}$ cells are well established in MS patients. van den $\overrightarrow{\vec{S}}$ Noort and Stjernholm ${ }^{37}$ have demonstrated a lymphocytotoxic factor in the sera of MS which inhibits RNA synthesis in stimulated lymphocytes $\frac{\bar{\sigma}}{\omega}$. and its titre correlates with disease activity and also $\overrightarrow{\widetilde{d}}$ with a lowered number of lymphocytes. The relative $\varrho$

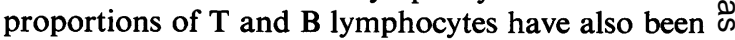
shown to vary in MS patients. Oger et $\boldsymbol{a l}^{\mathbf{3 8}}$ found an $\overrightarrow{0}$ increased proportion of $B$ cells, while others report no change ${ }^{39}$ or an increased proportion of T cells. ${ }^{40} \vec{\omega}$ Our own studies on the proportions of T and B cells in these patients, using AET treated sheep RBC to $\widehat{0}$ identify rosette forming $\mathrm{T}$ lymphocytes, ${ }^{41}$ gave high त $^{4}$ proportions ( $>80 \% \mathrm{~T}$ cells) in two cases, normal (55 or to $65 \% \mathrm{~T}$ cells) in three cases, and low $(<55 \% \dot{\omega}$ $\mathrm{T}$ cells) in four cases. Recent studies using mono- $N$ clonal antibodies have shown convincing changes among T lymphocyte subsets in MS patients with a marked reduction in T5/T8 (suppressor-cytotoxic) cells during the active phase of the disease. ${ }^{42-44} \mathrm{MS}$ 을 patients have also been shown to be deficient in $\underset{\Phi}{\mathscr{D}}$ natural killer cells and NK precursors induced by interferon..$^{45}$ There is clear but limited evidence for $\oplus^{\infty}$ differences in background SCE frequencies in $\omega$ different subpopulations of lymphocytes ${ }^{46}$ so that the evidently altered lymphocyte profile in MS might be considered as the cause for the increased basal levels of SCE in lymphocytes.

The results on SCE incidence in lymphocytes from $\frac{\Phi}{8}$ MS patients and controls exposed in vitro to the $\overrightarrow{\vec{P}}$ mutagens MMC and EMS are summarised in fig 3 . The pooled data show a dose dependent increase in SCE frequency for each of the two mutagens, with the SCE incidence in MS cells being consistently
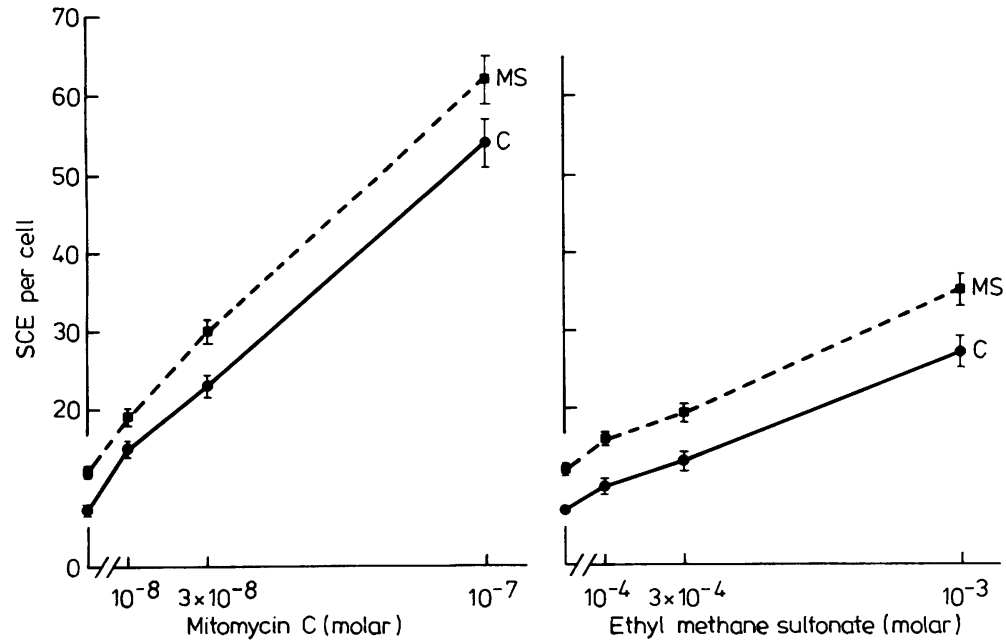

FIG 3 Yields of SCE in cultured lymphocytes of nine controls (O-O) and nine MS patients ( $\square---\square)$ following exposure to $M M C$ and EMS in vitro. Each point is the mean value $( \pm S E)$ from 180 cells. 
higher than in cells from controls. However, the dose response curves for MS cells are parallel to those of control cells, so that the difference between these two groups is simply a reflection of their basal differences in SCE incidence and is not a consequence of any differential sensitivity to the mutagens. Our findings therefore do not support the suggestion of possible anomalies in DNA repair in MS patients. ${ }^{17}$

In conclusion, our evidence would suggest that the enhanced basal SCE frequency in MS lymphocytes is a consistent finding which, on the basis of the mutagen experiments, does not appear to be a consequence of mutagen hypersensitivity associated with abnormal DNA repair. This enhancement would appear to be associated with alterations in lymphocyte population structure, but whether these alterations are themselves a consequence of viral infection remains to be established, and the possibility that the raised SCE incidence is, at least in part, directly rather than indirectly associated with virus infection cannot be discounted.

\section{References}

1 Poskanzer DC, Prenney LB, Sheridan JL, Yon Kondy J. Multiple sclerosis in the Orkney and Shetland Islands. I. Epidemiology, clinical factors, and methodology. J Epidemiol Commun Health 1980;34:229-39.

2 Jersild C, Svejgaard A, Fog T, Ammitzboll T. HL-A antigens and diseases. I. Multiple sclerosis. Tissue Antigens $1973 ; 3: 243-50$.

3 Dausset J, Hors J. Some contributions of the HL-A complex to the genetics of human diseases. Transplant Rev 1975;22:44-74.

4 Field EJ, Meyer-Rienecker HJ, Shenton BK, Jenssen HL. Anomalous lymphocyte-antigen reaction in relatives of multiple sclerosis patients. A study of possible genetic factors in the disease. $J$ Neurol 1977;216:135-46.

5 Editorial. The aetiology of multiple sclerosis. Lancet $1981 ; \mathbf{i}: 1347-8$.

6 Fraser KB. Multiple sclerosis: a virus disease? $\mathrm{Br} \mathrm{Med}$ Bull 1977;33:34-9.

7 Mertin J, Meade CJ. Relevance of fatty acids in multiple sclerosis. Br Med Bull 1977;33:67-71.

8 Acheson ED. Epidemiology of multiple sclerosis. Br Med Bull 1977;33:9-14.

9 Knight SC, Harding B, Burman S, Mertin J. Cell number requirements for lymphocyte stimulation in vitro: changes during the course of multiple sclerosis and the effects of immunosuppression. Clin Exp Immunol 1981; 46:61-9.

10 Waksman BH. Current trends in multiple sclerosis research. Immunology Today $1981 ;$ May:87-93.

11 Taylor AMR, Harnden DG, Arlett CF, et al. Ataxia telangiectasia: a human mutation with abnormal radiosensitivity. Nature $1975 ; 258: 427-9$.

12 Taylor AMR. Unrepaired DNA strand breaks in irradiated ataxia telangiectasia lymphocytes suggested from cytogenetic observations. Mutat Res 1978;50:407-18.

13 Paterson MC, Smith PJ. Ataxia telangiectasia: an inherited human disorder involving hypersensitivity to ionizing radiation and related DNA-damaging chemicals. Annu Rev Genet 1979;13:291-318.
14 Cleaver JE, Bootsma D. Xeroderma pigmentosum: biochemical and genetic characteristics. Annu Rev Genet $1975 ; 9: 19-38$.

15 Andrews AD, Barrett SF, Robbins JH. Relation of DNA repair processes to pathological ageing of the nervous system in xeroderma pigmentosum. Lancet 1976; : 1318-20.

16 Robbins JH. Significance of repair of human DNA: evidence from studies of xeroderma pigmentosum. $J$ Natl Cancer Inst 1978;61:645-56.

17 Sutherland GR, Baker E, Seshadri RS, Black A. Increased sister-chromatid exchange in multiple sclerosis. $N$ Engl J Med 1980;303:1126.

18 Gipps E, Kidson C. Ionising radiation sensitivity in multiple sclerosis. Lancet $1981 ; \mathbf{i}: 947$.

19 McDonald WI, Halliday AM. Diagnosis and classification of multiple sclerosis. Br Med Bull 1977;33:4-8.

20 Perry PE, Wolff S. New Giemsa method for the differential staining of sister chromatids. Nature 1974;251: 156-8.

21 Jensen MK. Lymphocyte transformation in multiple sclerosis. Acta Neurol Scand 1968;44:200-6.

22 Dau PC, Peterson RDA. Transformation of lymphocytes from patients with multiple sclerosis. Arch Neurol 1970; 23:32-40.

23 Davis LE, Hersh EM, Curtis JE, et al. Immune status of patients with multiple sclerosis. Analysis of primary and established immune responses in 24 patients. Neurology (Minneap) 1972;22:987-97.

24 Knight SC, Lance EM, Abbosh J, Munro A, O'Brien J. Intensive immunosuppression in patients with disseminated sclerosis. III. Lymphocyte response in vitro. Clin Exp Immunol 1975;21:23-31.

25 Lamourex G, Giard N, Jolicoeur R, Toughlian V, Desrosiers $M$. Immunological features in multiple sclerosis. Br Med J 1976;i:183-6.

26 Ockey CH. Differences between "spontaneous" and induced sister-chromatid exchanges with fixation time and their chromosome localization. Cytogenet Cell Genet 1980;26:223-35.

27 Lindblad A, Lambert B. Relation between sister chromatid exchange, cell proliferation and proportion of $B$ and $T$ cells in human lymphocyte cultures. Hum Genet 1981 ;57: 31-4.

28 ter Meulen V, Koprowski H, Iwasaki Y, Käckell YM, Müller D. Fusion of cultured multiple-sclerosis brain cells with indicator cells: presence of nucleocapsids and virions and isolation of parainfluenza-type virus. Lancet $1972 ; \mathrm{ii}: 1-5$.

29 Martin JR. Herpes simplex virus types 1 and 2 and multiple sclerosis. Lancet $1981 ;$ ii :777-81.

${ }^{30}$ Karcher D, Loewenthal A, Strosberg AD, eds. Humoral immunity in neurological disease. New York: Plenum Press, 1979.

31 Cremer NE, Johnson KP, Fein G, Likosky WH. Comprehensive viral immunology of multiple sclerosis. II. Analysis of serum and CSF antibodies by standard serological methods. Arch Neurol 1980;37:610-5.

32 Bauer HJ, Poser S, Ritter G, eds. Progress in multiple sclerosis research. Berlin: Springer-Verlag, 1980.

${ }^{33}$ Haire M, Fraser KB, Millar JHD. Measles and other virus-specific immunoglobulins in multiple sclerosis. $\mathrm{Br}$ Med J 1973;2:612-5.

34 Knuutila S, Mäki-Paakkanen J, Kähkönen $M$, Hokkanen E. An increased frequency of chromosomal changes and SCEs in cultured blood lymphocytes of 12 subjects vaccinated against smallpox. Hum Genet 1978; $41: 89-96$. 
35 Lambert B, Ehrnst A, Hansson K, Lindblad A, Morad M, Werelius B. Sister chromatid exchange in peripheral lymphocytes of subjects vaccinated against measles. Hum Genet 1979;50:291-6.

36 Harnden DG. Viruses, chromosomes, and tumors: the interaction between viruses and chromosomes. In: German J, ed. Chromosomes and cancer. New York: Wiley, 1974:152-90.

37 van den Noort S, Stjernholm RL. Lymphotoxic activity in multiple sclerosis serum. Neurology (Minneap) 1971 ;21 : 783-93.

38 Oger JF, Arnason BGW, Wray SH, Kistler JP. A study of $\mathrm{B}$ and $\mathrm{T}$ cells in multiple sclerosis. Neurology (Minneap) 1975;25:444-7.

39 Sandberg-Wollheil M, Turesson I. Lymphocyte subpopulations in the cerebrospinal fluid and peripheral blood in patients with multiple sclerosis. Scand J Immunol 1975;4:831-6.

40 Lisak RP, Levinson AI, Zweiman B, Abdou NI. T and B lymphocytes in multiple sclerosis. Clin Exp Immunol $1975 ; 22: 30-4$.

41 Kaplan ME, Clarke C. An improved rosetting assay for detection of human T lymphocytes. J Immunol Methods $\underset{\mathscr{D}}{\longrightarrow}$ $1974 ; 5: 131-5$.

42 Reinherz EL, Weiner HL, Hauser SL, Cohen JA, $\overline{\bar{C}}$ Distaso JA, Schlossman SF. Loss of suppressor T cells in active multiple sclerosis. Analysis with monoclonal antibodies. $N$ Engl J Med 1980;303:125-9.

43 Bach MA, Phan-Dinh-Tuy F, Tournier E, Chatenoud L, $\overline{\bar{D}}$ Bach J-F. Deficit of suppressor T cells in active multiple $\overrightarrow{\mathrm{D}}$ sclerosis. Lancet 1980;ii:1221-3.

44 Trotter JL, Rodey GE, Gebel HM. Azathioprine de- ஹొ creases suppressor $T$ cells in patients with multiple sclerosis. N Engl J Med 1982;306:365-6.

45 Bloom BR. Immunological changes in multiple sclerosis. Nature 1980;287:275-6.

46 Santesson B, Lindahl-Kiessling K, Mattsson A. SCE in B and T lymphocytes. Possible implications for Bloom's syndrome. Clin Genet 1979;16:133-5.

Correspondence and requests for reprints to $\mathrm{Dr}$ نr Vijayalaxmi, MRC Clinical and Population Cyto- $\omega$ genetics Unit, Western General Hospital, Crewe $N$ Road, Edinburgh EH4 2XU. 